\title{
Tissue Transglutaminase Expression Associates With Progression of Multiple Sclerosis
}

Claudia Sestito, PhD, Cyra E. Leurs, MD, PhD,* Martijn D. Steenwijk, PhD,* John J.P. Brevé, BASc, Jos W.R. Twisk, PhD, Micha M.M. Wilhelmus, PhD, Benjamin Drukarch, MD, PhD, Charlotte E. Teunissen, PhD, Anne-Marie van Dam, PhD, $†$ and Joep Killestein, MD, PhD $†$

Neurol Neuroimmunol Neuroinflamm 2021;8:e998. doi:10.1212/NXI.0000000000000998

\section{Abstract}

\section{Objective}

The clinical course of multiple sclerosis (MS) is variable and largely unpredictable pointing to an urgent need for markers to monitor disease activity and progression. Recent evidence revealed that tissue transglutaminase (TG2) is altered in patient-derived monocytes. We hypothesize that blood cell-derived TG2 messenger RNA (mRNA) can potentially be used as biomarker in patients with MS.

\section{Methods}

In peripheral blood mononuclear cells (PBMCs) from 151 healthy controls and 161 patients with MS, TG2 mRNA was measured and correlated with clinical and MRI parameters of disease activity (annualized relapse rate, gadolinium-enhanced lesions, and T2 lesion volume) and disease progression (Expanded Disability Status Scale [EDSS], normalized brain volume, and hypointense T1 lesion volume).

\section{Results}

PBMC-derived TG2 mRNA levels were significantly associated with disease progression, i.e., worsening of the EDSS over 2 years of follow-up, normalized brain volume, and normalized gray and white matter volume in the total MS patient group at baseline. Of these, in patients with relapsing-remitting MS, TG2 expression was significantly associated with worsening of the EDSS scores over 2 years of follow-up. In the patients with primary progressive (PP) MS, TG2 mRNA levels were significantly associated with EDSS, normalized brain volume, and normalized gray and white matter volume at baseline. In addition, TG2 mRNA associated with T1 hypointense lesion volume in the patients with PP MS at baseline.

\section{Conclusion}

PBMC-derived TG2 mRNA levels hold promise as biomarker for disease progression in patients with MS.

\section{Classification of Evidence}

This study provides Class II evidence that in patients with MS, PBMC-derived TG2 mRNA levels are associated with disease progression.
Correspondence

Dr. van Dam

amw.vandam@amsterdamumc.nl
MORE ONLINE

$\rightarrow$ Class of Evidence

Criteria for rating therapeutic and diagnostic studies

NPub.org/coe 


\section{Glossary}

3D = 3 dimensional; ARR = annualized relapse rate; $\mathbf{c D N A}=$ complementary DNA; DMD = disease-modifying drug; EAE = experimental autoimmune encephalomyelitis; EDSS = Expanded Disability Status Scale; HC = healthy control; HPRT1 = hypoxanthine phosphoribosyltransferase $1 ; \mathbf{I Q R}=$ interquartile range; $\mathbf{m R N A}=$ messenger RNA; $\mathbf{M S}$ = multiple sclerosis; NBV = normalized total brain volume; NfL = neurofilament light chain; NGMV = normalized total gray matter volume; NWMV = normalized white matter volume; PBMC $=$ peripheral blood mononuclear cell; PD = proton density; POLR2F = polymerase (RNA) II polypeptide F; $\mathbf{P P}=$ primary progressive; $\mathbf{q P C R}$ = quantitative real-time PCR; $\mathbf{R R}$ = relapsing-remitting; $\mathbf{S P}=$ secondary progressive; T1LV = lesion volumes T1 hypointense lesion; T2LV = lesion volumes for T2 lesions; TE = echo time; TG2 = tissue transglutaminase; $\mathbf{T I}=$ inversion time; $\mathbf{T R}=$ repetition time.

Multiple sclerosis (MS) is a chronic inflammatory, neurodegenerative disease of the CNS. ${ }^{1-4}$ It is the most frequent neurologic disease leading to permanent disability in young adults. The severity and clinical course varies among patients and is largely unpredictable., ${ }^{5,6}$ Nowadays, only few biomarkers are clinically used of which the majority detect conversion from clinically isolated syndrome to MS or response to treatment. ${ }^{7}$ Moreover, most of them rely on CSF collection, which is an invasive procedure. Neurofilament light chain (NfL) is emerging as the most promising biomarker in MS. However, NfL correlates less accurately with disease progression. ${ }^{8}$ Therefore, there is an unmet need for blood-derived biomarkers that predict MS progression.

Tissue transglutaminase (TG2) is a $\mathrm{Ca}^{2+}$-dependent multifunctional enzyme known for its protein cross-linking activity involved in the apoptotic pathway ${ }^{9,10}$ and membrane trafficking $^{11,12}$ as well as involvement in cell adhesion processes, including that of monocytes/macrophages. ${ }^{13}$ A role for TG2 in the pathogenesis of several neurodegenerative disorders, including Alzheimer disease, has been established. ${ }^{14}$ In a previous study in a rat model of MS (chronic relapsing experimental autoimmune encephalomyelitis $[\mathrm{EAE}]$ ), we observed that inhibition of TG2 activity reduced monocyte infiltration into the CNS as well as clinical symptoms. ${ }^{15}$ Moreover, in those rats as well as in human MS lesions, TG2positive macrophages were found. ${ }^{15,16}$ In addition, TG2 has been proposed to contribute to encephalitogenic T-cell differentiation in EAE ${ }^{17}$ These findings suggest a role for bloodderived leukocytes, which may enter the brain, contributing to MS pathology.

The clinical implications of TG2 have already been described for several human diseases. Indeed, TG2 can be used as a biomarker for cervical dysplasia. ${ }^{18}$ Furthermore, antiTG2 antibodies are used as a serologic marker for Coeliac disease's diagnosis. ${ }^{19,20}$ Nevertheless, the potential application of TG2 as a blood-derived biomarker in MS has not been studied yet.

Hence, we aimed to assess whether peripheral blood mononuclear cell (PBMC)-derived TG2 is altered in patients with MS and whether TG2 messenger RNA (mRNA) associates with disease activity and/or progression.

\section{Methods}

\section{Subjects}

From the MS Center Amsterdam (VU University Medical Center), a total of 169 patients with MS were included from the GeneMSA cohort in the years 2004 and 2005. Patients were diagnosed with MS according to the McDonald Diagnostic Criteria $^{21}$ and also further classified either as patients with relapsing-remitting $(R R ; n=111)$, secondary progressive $(\mathrm{SP} ; \mathrm{n}=36)$, or primary progressive $(\mathrm{PP} ; \mathrm{n}=22) \mathrm{MS}^{22}$ Disability was scored at the baseline visit and after 2 years using a numerical scale of the Expanded Disability Status Scale (EDSS). ${ }^{23}$ The annualized relapse rate (ARR) was based on the average number of relapses per year occurring between baseline and 2-year follow-up. Inclusion criteria for patients with MS were (1) age between 18 and 65 years; (2) EDSS ranging between 0 and 7.5; (3) at MRI, all patients had been relapse-free and steroid-free for at least 1 month, and (4) able and willing to sign an informed consent form. In addition, a total of 157 healthy control (HC) volunteers were included (blood only). Inclusion criteria for HCs were (1) age between 18 and 65 years and (2) able and willing to sign an informed consent form. Exclusion criteria were (1) a past history or current diagnosis of any clinically relevant neurologic, oncologic, or autoimmune disease including MS and (2) being related to a case or another control.

At baseline, in the RR MS group, 37\% of the patients ( $n=39$ ) were treated with disease-modifying drugs (DMDs; $\mathrm{n}=9$ glatiramer acetate; $\mathrm{n}=29$ interferon- $\beta ; \mathrm{n}=1$ mitoxantrone). In the SP MS group, $22.2 \%$ of the patients $(n=8)$ were treated with DMD $(\mathrm{n}=2$ glatiramer acetate; $\mathrm{n}=6$ interferon$\beta)$. In the PP MS group, $9.1 \%$ of the patients $(n=2)$ were treated with DMD ( $\mathrm{n}=1$ interferon- $\beta ; \mathrm{n}=1$ methotrexate).

\section{Standard Protocol Approvals, Registrations, and Patient Consents}

The study was approved by the local ethical committee. Written informed consent was obtained from all participants.

\section{Isolation of Primary Human Peripheral Blood Mononuclear Cells}

At the baseline visit, peripheral blood was drawn by venipuncture and collected into EDTA tubes (Becton Dickinson). These were centrifuged within 4 hours after blood collection. 
Table 1 Demographic and Clinical Information of the Study Cohort

\begin{tabular}{|c|c|c|c|c|c|}
\hline & $\mathrm{HC}$ & MS & RR MS & SPMS & PPMS \\
\hline $\mathbf{N}$ & 151 & 161 & 103 & 36 & 22 \\
\hline Male/female & $57 / 94$ & $68 / 93$ & $38 / 65$ & $16 / 20$ & $14 / 08$ \\
\hline Age at $B L, y$, mean $\pm S D$ & $41.9 \pm 11.5$ & $45 \pm 10$ & $42.7 \pm 10$ & $51.4 \pm 7.2$ & $51.6 \pm 7.9$ \\
\hline Disease duration at $B L, y$, mean \pm SD & NA & $10.6 \pm 7.5$ & $8.7 \pm 6.7$ & $17.2 \pm 7.1$ & $9.1 \pm 5.4$ \\
\hline ARR (2 y), mean \pm SD & NA & $0.10 \pm 0.35$ & $0.16 \pm 0.43$ & $0.014 \pm 0.08$ & NA \\
\hline EDSS at BL, mean (range) & NA & $3.9(0-7.5)$ & $3(0-6.5)$ & $5.6(2-7.5)$ & $5.1(2-7.5)$ \\
\hline EDSS at 24 mo, mean (range) & NA & $4.1(1-8)$ & $3.3(1-6.5)$ & $6.0(3-8)$ & $5.5(1.5-8)$ \\
\hline $\mathrm{NBV}$ at $\mathrm{BL}, \mathrm{mL}$, mean $\mathrm{mL} \pm \mathrm{SD}$ & NA & $1,500 \pm 98.4$ & $1,151 \pm 104$ & $1,465 \pm 88$ & $1,500 \pm 75.6$ \\
\hline $\mathrm{NGMV}$ at $\mathrm{BL}, \mathrm{mL}$, mean $\pm \mathrm{SD}$ & NA & $743 \pm 60.8$ & $754 \pm 61.9$ & $715 \pm 54.4$ & $730 \pm 51.1$ \\
\hline $\mathrm{NWMV}$ at $\mathrm{BL}, \mathrm{mL}$, mean $\pm \mathrm{SD}$ & NA & $757 \pm 50.4$ & $757 \pm 52.9$ & $750 \pm 52.4$ & $769 \pm 32.2$ \\
\hline T2LV at BL, median (25-75 percentile) & NA & $3.4(1.5-9.7)$ & $3.56(1.6-10.2)$ & $3.8(2.2-13.7)$ & $2.03(0.8-4.5)$ \\
\hline T1LV at BL, median (25-75 percentile) & NA & $0.61(0.1-2.9)$ & $0.54(0.1-2.6)$ & $1.36(0.4-5.7)$ & $0.22(0.1-1.6)$ \\
\hline Relapse during 2-y follow-up (yes/no) & NA & $16 / 145$ & $15 / 88$ & NA & NA \\
\hline $\mathrm{Gd}^{+}$at BL (yes/no/unknown) & NA & $39 / 120 / 2$ & $29 / 72 / 2$ & $8 / 28 / 0$ & $2 / 20 / 0$ \\
\hline DMT at BL (untreated/treated) ${ }^{a}$ & NA & $112 / 49$ & $64 / 39$ & $28 / 8$ & $20 / 2$ \\
\hline
\end{tabular}

Abbreviations: $\mathrm{ARR}=$ annualized relapse rate; $\mathrm{BL}=$ baseline; $\mathrm{DMT}=$ disease-modifying treatment; $\mathrm{EDSS}=$ Expanded Disability Status Scale; $\mathrm{Gd}{ }^{+}=$gadolinium $^{-}$ enhancing lesions; $\mathrm{HC}=$ healthy control; $\mathrm{MS}=$ whole MS group; $\mathrm{NA}=$ not applicable; NBV = normalized brain volume; NGMV = normalized gray matter volume; $\mathrm{NWMV}=$ normalized white matter volume; $\mathrm{RR}=$ relapsing-remitting; $\mathrm{SP}=$ secondary progressive; $\mathrm{PP}$ = primary progressive; $\mathrm{T} 1 \mathrm{LV}=\mathrm{T} 1$ lesion volume; $\mathrm{T} 2 \mathrm{LV}=\mathrm{T} 2$ lesion volume.

${ }^{\text {a }}$ Treatment description to be found in the Methods section.

PBMCs were isolated from the 169 patients with MS and 157 HCs by density centrifugation using Ficoll (Ficoll Isopaque PLUS; GE Healthcare, Chicago, IL) and immediately stored in liquid nitrogen until further processing. No differences were reported regarding sample handling between MS and HC groups.

\section{mRNA Isolation and cDNA Synthesis}

Total RNA was isolated from primary human PBMCs using TRIzol Reagent (Invitrogen, Carlsbad, CA) according to the manufacturer's instructions. Total RNA was further purified using the MicroElute RNA clean up kit (Omega Bio-Tek, Norcross, GA). The RNA purity was assessed using the NanoDrop 1000 (Thermo Scientific, Waltham, MA). The quality ratios $260 / 280$ and 260/230 were above 1.9 and 1.7 , respectively, for all samples included in the study. Total RNA $(200 \mathrm{ng} / \mathrm{sample})$ was reverse transcribed into complementary DNA (cDNA) using the High-Capacity cDNA Reverse Transcription Kit (Applied Biosystems, Foster City, CA) according to the manufacturer's instructions.

\section{Semiquantitative Real-Time PCR}

For semiquantitative real-time PCR (qPCR), the Power SYBR Green Master Mix (Applied Biosystems) was used. The following primer sequences (Eurogentec, Maastricht, the Netherlands) were used: TG2 forward 5' -AGAGGAGCGGCAGGAGTATG3', TG2 reverse 5'-AGGATCCCATCTTCAAACTGC-3',
HPRT1 forward 5'-AGCCCTGGCGTCGTGATTAGT-3', HPRT1 reverse 5'-CGAGCAAGACGTTCAGTCCTGTCC3', POLR2F forward 5'-GAACTCAAGGCCCGAAAG-3', POLR2F reverse 5' -TGATGATGAGCTCGTCCAC-3'. qPCR was performed in LightCycler 480 Multiwell Plate 384 (Roche, Basel, Switzerland) on a LightCycler 480 Real-Time PCR System (Roche). The reaction mixture $(10 \mu \mathrm{L})$ was composed of $1 \times$ Power SYBR Green buffer (Applied Biosystems), $1.86 \mathrm{pmol}$ of each primer, and 5 ng cDNA. The thermal cycling conditions were an initial 10 minutes at $95^{\circ} \mathrm{C}$ followed by 50 cycles of 15 seconds at $95^{\circ} \mathrm{C}$ and 1 minute at $60^{\circ} \mathrm{C}$. The specificity of the reaction was checked by melt curve analysis of the individual qPCR reactions. The relative expression level of TG2 was determined by the LinRegPCR software (version 2014.3; website: hfrc.nl) using the following calculation $\mathrm{NO}=\mathrm{Nq} / \mathrm{ECq}(\mathrm{NO}=$ target quantity, $\mathrm{Nq}=$ fluorescence threshold value, $\mathrm{E}=$ mean PCR efficiency per amplicon, and Cq $=$ threshold cycle) ${ }^{24}$ after which the value was normalized relative to the geometric mean of the mRNA levels hypoxanthine phosphoribosyltransferase 1 (HPRT1) and polymerase (RNA) II polypeptide F (POLR2F). HPRT1 and POLR2F were chosen as reference genes as being most stably expressed based on the results of the GeNorm software analysis (version 3.5) in which the stability of 6 different human housekeeping genes (GAPDH, MRIP, POLR2F, HPRT1, PGK1, and SDHA) was assessed in a random selection of MS and HC subject samples. 
Table 2 Linear Regression Analyses Comparing TG2 mRNA Levels Between Subject Groups

\begin{tabular}{lllll}
\hline & $\boldsymbol{p}$ Value & & \multicolumn{2}{l}{$\mathbf{9 5 \% \mathrm { Cl }}$} \\
\cline { 3 - 5 } HC vs MS & 0.274 & Ratio & Lower bound & Upper bound \\
\hline HC vs RR & 0.013 & 0.91 & 0.78 & 0.95 \\
\hline HC vs SP & 0.320 & 0.80 & 0.67 & 1.07 \\
\hline HC vs PP & 0.079 & 1.14 & 0.88 & 1.49 \\
\hline RR vs SP & 0.011 & 1.33 & 0.97 & 1.86 \\
\hline RR vs PP & 0.002 & 1.43 & 1.08 & 1.88 \\
\hline PP vs SP & 0.411 & 1.67 & 1.20 & 1.34 \\
\hline
\end{tabular}

Abbreviations: $\mathrm{HC}$ = healthy control; $\mathrm{mRNA}$ = messenger RNA; MS = whole MS group; $\mathrm{RR}$ = relapsing-remitting; $\mathrm{SP}$ = secondary progressive; $\mathrm{PP}$ = primary progressive; ratio $=\operatorname{Exp}(B)$, exponentiation of the $B$ coefficient; TG2 $=$ tissue transglutaminase.

HC: M 0.41 (0.24-0.65); MS: M 0.37 (0.22-0.61); RR: M 0.35 (0.17-0.57); SP: M $0.43(0.26-0.73) ;$ PP: M $0.46(0.28-1.13)$. TG2 mRNA levels were not normally distributed, and therefore, the natural logarithm was taken. TG2 mRNA distribution in the different groups is expressed as median (IQR).

\section{MRI Acquisition and Analysis}

Of the patients with MS, imaging was performed at the baseline visit on a $1.5 \mathrm{~T}$ MRI scanner (Siemens Vision using the standard circularly polarized head-coil) using a standardized and previously described protocol. ${ }^{25}$ The protocol included 3-dimensional (3D) T1-weighted images (repetition time [TR]: 9.7-20.8 milliseconds; echo time [TE]: 2-4 milliseconds; inversion time [TI]: 300-400 milliseconds) for brain volume measurements, consisting of $1.0 \mathrm{~mm}$-thick slices and a $1.0 \times 1.0 \mathrm{~mm}^{2}$ in plane resolution. In addition, dual echo proton density (PD)-T2-weighted images (TR: 2,000-4,000 milliseconds; TE: $14-20 / 80-108$ milliseconds), with interleaved axial $3.0 \mathrm{~mm}$-thick slices and an in plane resolution of $1.0 \times 1.0 \mathrm{~mm}^{2}$ and postcontrast $\mathrm{T} 1$ weighted spin-echo images (TR: 467-650 milliseconds; TE: 8-17 milliseconds; axial $3.0 \mathrm{~mm}$-thick slices with an in plane resolution of $1.0 \times 1.0 \mathrm{~mm}^{2}$ ) were obtained for lesion quantification.

Two independent, trained, and experienced raters (employees of the former Image Analysis Center Amsterdam) manually outlined $\mathrm{T} 2$ hyperintense lesions on the $\mathrm{PD} / \mathrm{T} 2$ images and $\mathrm{T} 1$ hypointense lesions on the $\mathrm{T} 1$-weighted spinecho images. Subsequently, lesion volumes for T2 lesions (T2LV) and T1 hypointense lesions (T1LV) were calculated. The number of gadolinium-enhancing brain lesions on postcontrast T1-weighted spin-echo images was scored.

Lesion filling was then applied to the 3D T1-weighted images to prevent an effect of hypointense lesions on brain volumetry. ${ }^{26}$ Whole-brain volumes were than calculated using SIENAX (part of FSL 5.0.4) and the recommended settings for brain extraction. ${ }^{27}$ The whole-brain volume was then normalized for differences in head size, resulting in normalized total brain volume (NBV), normalized total gray matter volume (NGMV), and normalized white matter volume (NWMV) at baseline.

\section{Statistical Analysis}

According to the interquartile range (IQR) rule, ${ }^{28} 6 \mathrm{HCs}$ and 8 patients with RR MS were excluded from all the analysis based on extreme TG2 mRNA levels (e.g., >1.5 IQR). To investigate whether TG2 mRNA levels were altered in patients with MS, linear regression analyses were performed with TG2 mRNA levels as outcome and MS vs control as independent variable. Besides, additional linear regression analyses were performed with the different MS subgroups as a categorical independent variable, in the model represented by dummy variables. Before analysis, TG2 mRNA levels of all (sub)groups were evaluated for normality by visual inspection. Because TG2 mRNA levels were not normally distributed, the logarithmic transformation of TG2 mRNA was used as dependent variable.

To investigate whether TG2 mRNA levels were related to disease activity and/or progression, linear regression analyses were used with TG2 mRNA levels as independent variable and EDSS, relative change in EDSS over 2-year follow-up, disease duration, NBV, NGMV, NWMV, T1LV, and T2LV as outcome variables. In all linear regression analyses, an adjustment was made for sex and age.

Because of the non-normal distribution of T1LV, T2LV and the relative change in EDSS, the linear regression analyses were performed on the log transformed outcomes.

In additional sex- and age-adjusted linear regression analyses, we also investigated either (1) the effect of DMDs on TG2 expression, (2) the differences in TG2 mRNA levels between patients with active/inactive disease (based on presence/ absence of gadolinium enhancing lesions), (3) the differences in TG2 mRNA levels regarding the presence/absence of relapses during follow-up, or (4) the association between TG2 mRNA and ARR as additional independent variables. In those 4 analyses, the logarithmic transformation of TG2 mRNA was used as a dependent variable. 
Table 3 Association of TG2 With Measures of Disease Activity

\begin{tabular}{|c|c|c|c|c|c|c|c|}
\hline \multirow[b]{2}{*}{ Type } & & \multicolumn{2}{|c|}{ Median of relative TG2 mRNA } & \multirow[b]{2}{*}{$p$ Value } & \multirow[b]{2}{*}{ Ratio } & \multicolumn{2}{|l|}{$95 \% \mathrm{Cl}$} \\
\hline & & Yes & No & & & Lower bound & Upper bound \\
\hline \multicolumn{8}{|l|}{ MS } \\
\hline \multicolumn{2}{|c|}{$\mathbf{G d}^{+}$at $\mathbf{B L}$} & 0.30 & 0.39 & 0.162 & 0.83 & 0.63 & 1.08 \\
\hline \multicolumn{2}{|c|}{ Relapse during follow-up } & 0.41 & 0.36 & 0.734 & 1.07 & 0.71 & 1.61 \\
\hline \multicolumn{2}{|c|}{ DMT at BL } & 0.35 & 0.38 & 0.643 & 0.94 & 0.73 & 1.21 \\
\hline \multicolumn{8}{|l|}{ RR } \\
\hline \multicolumn{2}{|c|}{$\mathrm{Gd}^{+}$at $\mathrm{BL}$} & 0.25 & 0.38 & 0.080 & 0.75 & 0.55 & 1.03 \\
\hline \multicolumn{2}{|c|}{ Relapse during follow-up } & 0.39 & 0.33 & 0.647 & 1.10 & 0.72 & 1.69 \\
\hline \multicolumn{2}{|c|}{ DMT at BL } & 0.30 & 0.35 & 0.922 & 0.98 & 0.73 & 1.32 \\
\hline & & & & & \multicolumn{2}{|c|}{$95 \% \mathrm{Cl}$} & \\
\hline ARR & \multicolumn{2}{|l|}{$p$ Value } & Std $\beta$ & Unstd B & \multicolumn{2}{|c|}{ Lower bound } & Upper bound \\
\hline \multicolumn{8}{|l|}{ Type } \\
\hline MS & \multicolumn{2}{|l|}{0.596} & 0.044 & 0.174 & \multicolumn{2}{|c|}{-0.251} & 0.435 \\
\hline $\mathbf{R R}$ & \multicolumn{2}{|l|}{0.489} & 0.073 & 0.176 & \multicolumn{2}{|c|}{-0.227} & 0.471 \\
\hline SP & NA & & NA & NA & $\mathrm{N}$ & & NA \\
\hline PP & NA & & NA & NA & $\mathrm{N}$ & & NA \\
\hline & & & & & & & \\
\hline $\log (T 2 L V)$ & $p$ Value & & $\operatorname{Std} \beta$ & Unstd B & & ound & Upper bound \\
\hline Type & & & & & & & \\
\hline MS & 0.979 & & -0.002 & 0.370 & & & 0.722 \\
\hline $\mathbf{R R}$ & 0.770 & & 0.029 & 0.579 & & & 1.320 \\
\hline SP & 0.091 & & -0.327 & 0.875 & & & 0.264 \\
\hline PP & 0.071 & & 0.434 & 0.559 & & & 2.248 \\
\hline
\end{tabular}

Abbreviations: $\mathrm{ARR}=$ annualized relapse rate; $\mathrm{BL}=$ baseline; $\mathrm{DMT}=$ disease-modifying treatment; $\mathrm{Gd}^{+}=$gadolinium-enhancing lesions; $\mathrm{mRNA}=\mathrm{messenger}$ RNA; $M S$ = whole MS group; NA = not applicable; $P P=$ primary progressive; ratio = Exp(B), exponentiation of the $B$ coefficient; $R R=$ relapsing-remitting; $S P=$ secondary progressive; Std $\beta=$ correlation coefficient; T2LV = T2 lesion volume; TG2 = tissue transglutaminase; Unstd B = unstandardized B coefficient.

$p<0.05$ was considered statistically significant. All the analyses were performed using SPSS version 22.0 (IBM Corp., Armonk, NY).

\section{Data Availability}

All the data are included in the article. Anonymized data can be shared by request from any qualified investigator.

\section{Results}

TG2 mRNA Levels in PBMCs of Patients With MS A total of $151 \mathrm{HCs}$ and 161 patients with MS were included in the study. The demographic and clinical characteristics of both groups are described in table 1.

First, we investigated the levels of TG2 mRNA in PBMCs derived from patients with MS and HCs. The linear regression analysis showed that TG2 mRNA levels were comparable between the 2 groups (median [IQR]: HC: 0.41 [0.24-0.65]; MS: 0.37 [0.22-0.61]; $p=0.274)$. In addition, RR MS patientderived PBMCs showed significantly lower levels of TG2 mRNA compared with that of HCs (median [IQR]: HC: 0.41 [0.24-0.65]; RR: 0.35 [0.17-0.57]; $p=0.013)$, whereas patients with PP MS tended to show higher TG2 mRNA levels than HCs (median [IQR]: HC: 0.41 [0.24-0.65]; PP: 0.46 (0.28-1.13); $p=0.079)$. Of interest, patients with SP MS and PP MS showed significantly higher TG2 mRNA levels compared with patients with RR MS (median [IQR]: SP: 0.43 [0.26-0.73]; RR: 0.35 [0.17-0.57]; $p=0.011$ and PP: 0.46 [0.28-1.13]; RR: 0.35 [0.17-0.57]; $p=0.002)$ (table 2).

\section{Association of TG2 mRNA With Measures of Disease Activity}

Next, we determined whether PBMC-derived TG2 expression has any potential relevance as read out for disease activity. 
Table 4 Association of TG2 With Measures of Disease Progression

\begin{tabular}{|c|c|c|c|c|c|c|c|c|c|c|c|c|c|c|c|c|}
\hline \multirow[b]{2}{*}{ MS type } & \multicolumn{4}{|l|}{ MS } & \multicolumn{4}{|l|}{ RR } & \multicolumn{4}{|l|}{ SP } & \multicolumn{4}{|l|}{ PP } \\
\hline & $\operatorname{Std} \beta$ & $p$ Value & $\begin{array}{l}\text { Unstd } \\
\text { B }\end{array}$ & $\begin{array}{l}\mathrm{Cl} \text { (lower/ } \\
\text { upper) }\end{array}$ & $\operatorname{Std} \beta$ & $\begin{array}{l}p \\
\text { Value }\end{array}$ & $\begin{array}{l}\text { Unstd } \\
\text { B }\end{array}$ & $\begin{array}{l}\mathrm{Cl} \text { (lower/ } \\
\text { upper) }\end{array}$ & $\operatorname{Std} \beta$ & $\begin{array}{l}p \\
\text { Value }\end{array}$ & $\begin{array}{l}\text { Unstd } \\
\text { B }\end{array}$ & $\begin{array}{l}\mathrm{Cl} \text { (lower/ } \\
\text { upper) }\end{array}$ & $\operatorname{Std} \beta$ & $p$ Value & $\begin{array}{l}\text { Unstd } \\
\text { B }\end{array}$ & $\begin{array}{l}\mathrm{Cl} \text { (lower/ } \\
\text { upper) }\end{array}$ \\
\hline DSS & 0.260 & $<0.001$ *** & 1.454 & $0.72 / 2.19$ & 0.047 & 0.613 & 0.252 & $\begin{array}{l}-0.733 / \\
1.237\end{array}$ & 0.368 & $0.032^{\star}$ & 1.555 & $0.144 / 2.966$ & 0.478 & $0.029 *$ & 1.455 & $0.166 / 2.743$ \\
\hline $\begin{array}{l}\text { og(rel. change EDSS } \\
-24 \mathrm{mo})\end{array}$ & 0.166 & 0.052 & 0.132 & $\begin{array}{l}-0.001 / \\
0.266\end{array}$ & 0.258 & $0.015^{*}$ & 0.28 & $0.056 / 0.505$ & -0.191 & 0.303 & -0.075 & $\begin{array}{l}-0.221 / \\
0.072\end{array}$ & 0.039 & 0.873 & 0.02 & $\begin{array}{l}-0.240 / \\
0.279\end{array}$ \\
\hline VBV & -0.180 & $0.015^{*}$ & -54.821 & $\begin{array}{l}-98.69 / \\
-10.95\end{array}$ & -0.148 & 0.096 & -60.572 & $\begin{array}{l}-132.01 / \\
10.868\end{array}$ & -0.177 & 0.368 & -50.611 & $\begin{array}{l}-164.13 / \\
62.91\end{array}$ & -0.564 & $0.007^{* \star}$ & -87.132 & $\begin{array}{l}-147.42 / \\
-26.85\end{array}$ \\
\hline VGMV & -0.148 & $0.033^{*}$ & -27.905 & $\begin{array}{l}-53.47 / \\
-2.34\end{array}$ & 0.122 & 0.159 & -29.710 & $\begin{array}{l}-71.29 / \\
11.87\end{array}$ & -0.049 & 0.797 & -86.751 & $\begin{array}{l}-77.18 / \\
59.83\end{array}$ & -0.427 & $0.022^{*}$ & -44.547 & $\begin{array}{l}-82.03 / \\
-7.06\end{array}$ \\
\hline NWMV & -0.172 & $0.030 *$ & -26.916 & $-51.23 /-2.6$ & -0.148 & 0.117 & -30.862 & $\begin{array}{l}-69.64 / \\
-7.92\end{array}$ & -0.246 & 0.212 & -41.936 & $\begin{array}{l}109.32 / \\
25.44\end{array}$ & -0.647 & $0.003 * \star$ & -42.585 & $\begin{array}{l}-69.01 / \\
-16.16\end{array}$ \\
\hline $.0 g(T 1 L V)$ & 0.048 & 0.543 & 0.394 & $\begin{array}{l}-0.880 / \\
1.667\end{array}$ & 0.009 & 0.925 & 0.096 & $\begin{array}{l}-1.918 / \\
2.110\end{array}$ & -0.043 & 0.809 & -0.341 & $\begin{array}{l}-3.193 / \\
2.510\end{array}$ & 0.476 & $0.046^{*}$ & 2.228 & $0.043 / 4.414$ \\
\hline
\end{tabular}

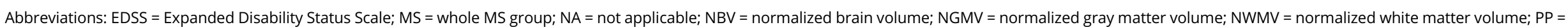

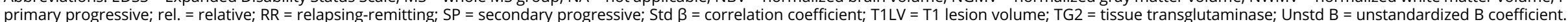
primary progressive; rel. = relative;
${ }^{\star} p<0.05 ;{ }^{* \star} p<0.01 ;{ }^{* \star} p<0.001$. 
We observed no significant association between PBMCderived TG2 mRNA levels and measures of disease activity. In fact, TG2 mRNA levels did not significantly associate with (1) the presence or absence of gadolinium-enhanced lesions, (2) presence of relapses during follow-up, (3) use of DMDs, and (4) ARR either in patients with MS or any MS subtype. In addition, no significant association was present between TG2 mRNA levels and T2LV (log (T2VL)) (table 3).

\section{Association of TG2 mRNA With Measures of Disease Progression}

In addition to disease activity, we determined whether PBMC-derived TG2 mRNA is potentially relevant as a read out for disease progression (table 4). Indeed, TG2 mRNA was associated with clinical disability, i.e., EDSS score at baseline in overall patients with MS (std. $\beta=0.260 ; p<0.0001$ ) (figure, A). Among these, TG2 mRNA levels associated with EDSS scores at baseline particularly in patients with SP MS $(\operatorname{std} \beta=0.368 ; p=0.032)$ and patients with PP MS $(\operatorname{std} \beta=$ 0.478 ; $p=0.029$ ) (figure, G). Of interest, in overall patients with MS and in particular in patients with RR MS, TG2 mRNA levels were associated with worsening of disability, as measured by the change in EDSS score, over a 2-year followup (log (EDSS): MS: std. $\beta=0.166 ; p=0.052$ and RR: $\beta=$ $0.258 ; p=0.015)$ (figure, $\mathrm{B}$ and $\mathrm{F}$, respectively).

Furthermore, considering all patients with MS, a significant association of TG2 mRNA with both NBV $(\operatorname{std} \beta=-0.180$; $p=0.015$ ), NGMV (std. $\beta=-0.148 ; p=0.033$ ), and NWMV (std. $\beta=-0.172 ; p=0.030$ ) at baseline was observed (figure, $\mathrm{C}-\mathrm{E}$, respectively). Of these, in particular in patients with PP MS, a significant association between TG2 mRNA levels and NBV ( $\operatorname{std} \beta=-0.564 ; p=0.007)$, NGMV $(\operatorname{std} \beta=-0.427 ; p=0.022)$, and NWMV $(\operatorname{std} \beta=-0.647$; $p=0.003$ ) at baseline was observed (figure, $\mathrm{H}-\mathrm{J}$, respectively).

Of interest, in PP MS patients also T1LV at baseline showed a significant association with TG2 expression levels (log (T1LV): $\operatorname{std} \beta=0.476 ; p=0.046$ ) (figure, $\mathrm{K}$ ).

\section{Discussion}

During the last decades, there has been an increasing interest in TG2 as a potential prognostic marker or therapy target in various human pathologies. ${ }^{29-31}$ Previous research has highlighted the possible role for TG2 in the pathogenesis of $\mathrm{MS}^{16,32}$ as well as in its animal model EAE. ${ }^{15,17,33}$ In search for potential novel blood-derived biomarkers, this study reports on PBMCderived TG2 mRNA levels in patients with MS, and in its clinical subtypes, in relation to markers of disease activity and progression.

First, we found no difference in TG2 mRNA levels between patients with MS as a group and HCs, probably due to high variability in expression levels in the group of patients with MS. Next, we observed that in PBMCs derived from patients with RR MS, significantly lower levels of TG2 mRNA were measured compared with HCs, whereas in PBMCs of patients with SP MS and PP MS, more TG2 mRNA was found compared with patients with RR MS. In a previous study, we observed clear enhanced levels of TG2 mRNA in bloodderived monocytes from patients with MS. ${ }^{34}$ The current study presents a different TG2 expression pattern in MS patient-derived PBMCs. Thus far, regulation of TG2 expression in the whole PBMC population has not been studied, but it is known that TG2 expression is induced in monocytes and macrophages by the anti-inflammatory cytokine interleukin- $4^{34,35}$ and vitamins D and A. ${ }^{36}$ Lymphocytes, in particular $\mathrm{T}$ cells, have also been described to produce TG2. ${ }^{37,38}$ Thus, our data may indicate that TG2 expression may be PBMC cell type, vitamin status, and inflammatory factor dependently regulated. Nevertheless, PBMC-derived TG2 mRNA levels do not differ between patients with MS and HCs, and therefore, as such, it cannot clearly discriminate between the 2 groups.

Regarding the association between TG2 and measures of disease activity (i.e., presence of a relapse, $\mathrm{ARR}, \mathrm{Gd}^{+}$lesions, and $\mathrm{T} 2$ lesion volume), no significant associations were found, suggesting that the presence of active disease in the CNS is not associated with the level of TG2 mRNA in PBMCs. Moreover, TG2 mRNA levels were not clearly associated with the use of DMDs, which target inflammatory processes ongoing during MS. Although TG2 expression has been shown to be regulated by inflammatory mediators, we did not find such an effect in our cohort of patients with MS. This can be due to the relatively low number of patients with MS with active disease at baseline when PBMCs were obtained.

In addition, association between TG2 expression and measures for disease progression was evaluated. Of interest, we observed that TG2 mRNA levels significantly associated with clinical and radiologic measures of disease progression; In fact, TG2 expression showed significant association with patients disability (EDSS) as well as NBV, NGMV, and NWMV at baseline in both the total group of patients with MS among which in particular in patients with PP MS. Furthermore, in patients with PP MS, TG2 mRNA was also significantly associated with T1LV. Together, these data indicate that in particular in patients with PP MS, PBMC-derived TG2 mRNA levels are associated with progression of the disease and axonal damage. Although the described associations were detected cross-sectionally, TG2 mRNA also showed some potential to associate with disease progression longitudinally; in fact, in the total group of patients with MS and in particular in the RR MS subtype, TG2 mRNA levels at baseline were associated with worsening of the clinical symptoms (change in EDSS) over a 2-year follow-up. Longitudinal correlations with disability progression that are largely driven by the RR MS group should be interpreted with some caution as changes in EDSS in the lower range occur rather easily and may also reflect lack of recovery after possible relapses in addition to more real disease progression. Lack of confirmation of the longitudinal associations in the separate progressive 

A. Patients with MS
B. Patients with MS
C. Patients with MS
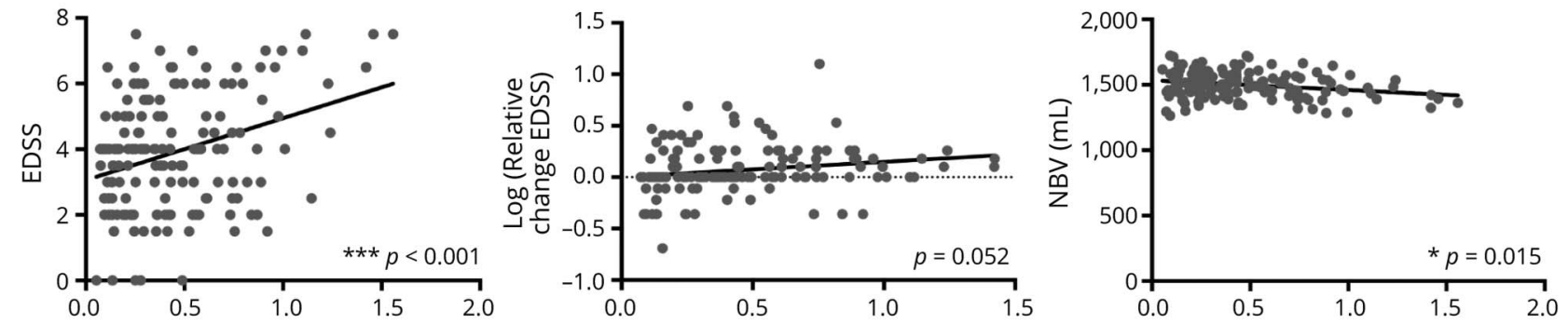

D. Patients with MS

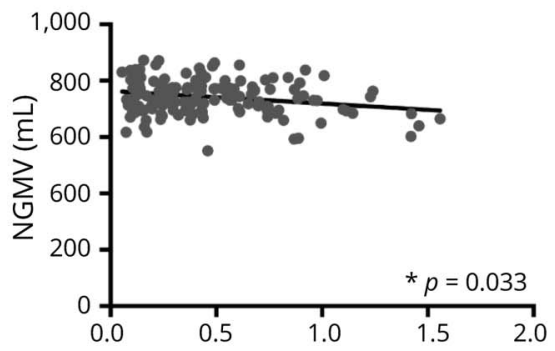

E. Patients with MS

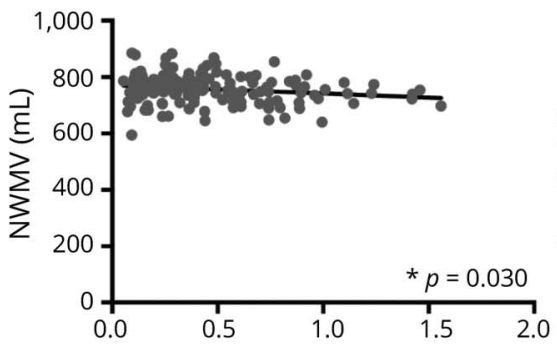

F. Patients with RR MS

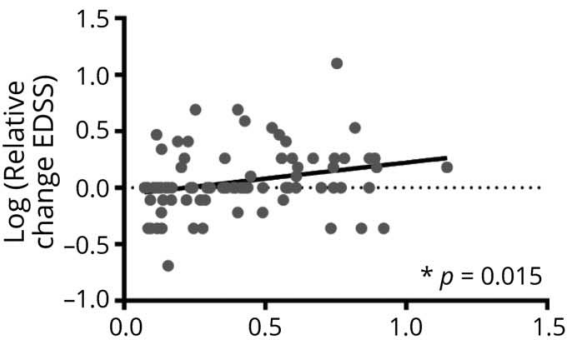

G. Patients with PP MS

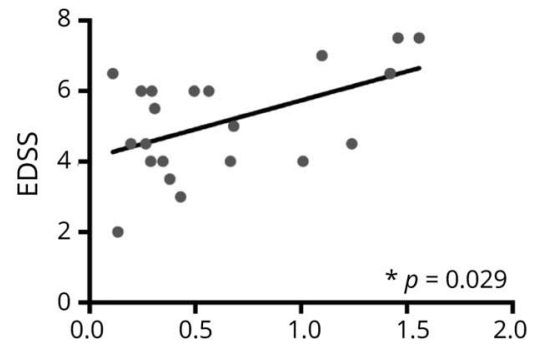

J. Patients with PP MS

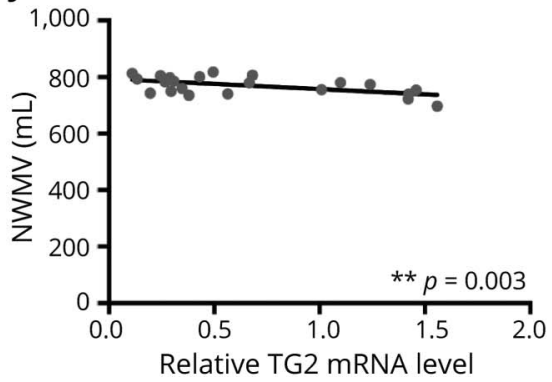

H. Patients with PP MS

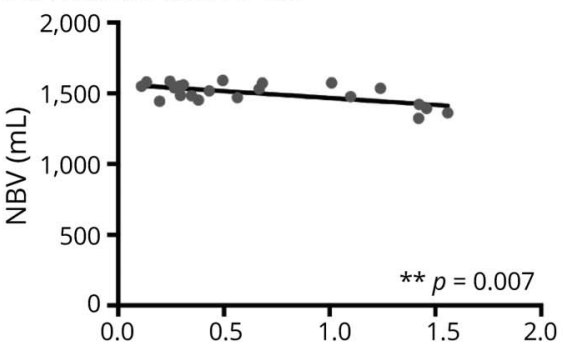

K. Patients with PP MS

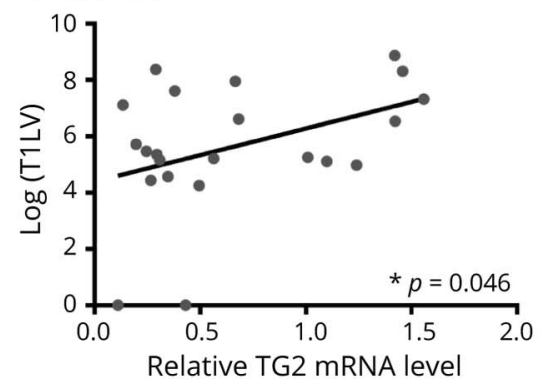

Association of PBMCs-derived TG2 mRNA levels with (A) Expanded Disability Status Scale (EDSS); (B) relative change of EDSS over 2 years follow-up; (C) normalized brain volume (NBV); (D) normalized gray matter volume (NGMV), and (E) normalized white matter volume (NWMV) in patients with MS. Association of PBMC-derived TG2 mRNA levels with (F) relative change of EDSS over 2-year follow-up in patients with RR MS (LogRelative Change EDSS). Association of PBMC-derived TG2 mRNA levels with (G) EDSS; (H) NBV; (I) NGMV; () NWMV; and (K) T1 lesions volume (T1LV) (LogT1LV). Linear regression analysis was performed controlling for sex and age. mRNA = messenger RNA; PBMC = peripheral blood mononuclear cell; TG2 = tissue transglutaminase

patient groups may have to do with both limited follow-up duration and possibly lack of power in the subgroups.

The goal of the present study was to perform an explorative analysis, we there for decided to not perform any adjustment for multiple testing. In a future validation study, this has to be taken into account. Still, our data point to PBMC-derived TG2 mRNA as biomarker for disease progression in patients with MS as group and more specifically in the PP MS or RR MS subgroups of patients with MS. Subsequent prospective, longitudinal studies in patients with MS are required to evaluate individual PBMCderived TG2 mRNA levels over the course of the disease in association with measures of disease activity and in particular, disease progression. This may eventually result in a patient 
predictive blood-derived biomarker for disease progression in patients with MS for which there is an unmet need. Moreover, biomarkers reliably measuring disease progression in MS are important to make timely decisions on treatment and early switches if needed. If confirmed, these biomarkers may potentially be useful to monitor progression both in trials testing new neuroprotective agents as well as in daily practice, e.g., monitoring progressive patients on therapies like ocrelizumab and siponimod.

To date, many of the proposed candidate biomarkers for MS disease activity and progression are measured in the CSF, which can only be collected through an invasive procedure, thus making a CSF-derived biomarker less patient friendly compared with a blood-derived marker, especially if repeated measurements are indicated. There is an urgent need for biomarkers that can predict and monitor long-term disease progression and reflect ongoing axonal damage specifically in progressive patients. Thus far, NfL seems to be most promising as a marker of MS disease activity and response to $\mathrm{DMDs}^{39-42}$ being also validated in serum samples. ${ }^{43,44}$ Although some recent articles also suggest correlations with disease progression in $\mathrm{MS},{ }^{8,43}$ this has to be confirmed. In addition, serum level of glial fibrillary acidic protein has been proposed as biomarker for disease severity in patients with PP MS, ${ }^{45}$ however, no association with MRI parameters was found. ${ }^{45}$

In conclusion, the novel findings reported in this study indicate that PBMCs-derived TG2 mRNA levels associate with clinical and radiologic measurements of MS disease progression and therefore hold promise as biomarker for disease progression in MS and especially in patients with PP MS.

\section{Study Funding}

This work was financially supported by EU Marie Curie ITN "TRANSPATH" (grant number 289964) and the Dutch Multiple Sclerosis (MS) Research foundation (grant number MS14-865).

\section{Disclosure}

The authors report no disclosures. Go to Neurology.org/NN for full disclosures.

\section{Publication History}

Received by Neurology: Neuroimmunology \& Neuroinflammation August 24, 2020. Accepted in final form February 22, 2021.

Appendix Authors

\begin{tabular}{lll}
\hline Name & Location & Contribution \\
\hline $\begin{array}{l}\text { Claudia } \\
\text { Sestito, } \\
\text { PhD }\end{array}$ & $\begin{array}{l}\text { Department of Anatomy } \\
\text { and Neurosciences, } \\
\text { Amsterdam UMC, the } \\
\text { Netherlands }\end{array}$ & $\begin{array}{l}\text { Conceived and performed } \\
\text { experiments, analyzed the } \\
\text { data, and wrote the paper }\end{array}$ \\
\hline $\begin{array}{l}\text { Cyra E. } \\
\text { Leurs, MD, } \\
\text { PhD }\end{array}$ & $\begin{array}{l}\text { Department of Neurology, } \\
\text { Amsterdam UMC, the }\end{array}$ & $\begin{array}{l}\text { Helped in clinical data } \\
\text { collection and interpretation } \\
\text { and in the writing of the } \\
\text { paper }\end{array}$ \\
\hline
\end{tabular}

Appendix (continued)

\begin{tabular}{|c|c|c|}
\hline Name & Location & Contribution \\
\hline $\begin{array}{l}\text { Martijn D. } \\
\text { Steenwijk, } \\
\text { PhD }\end{array}$ & $\begin{array}{l}\text { Department of Anatomy } \\
\text { and Neurosciences, } \\
\text { Amsterdam UMC, the } \\
\text { Netherlands }\end{array}$ & $\begin{array}{l}\text { Helped in clinical data } \\
\text { collection and interpretation } \\
\text { and in the writing of the } \\
\text { paper }\end{array}$ \\
\hline $\begin{array}{l}\text { John J.P. } \\
\text { Brevé, BASc }\end{array}$ & $\begin{array}{l}\text { Department of Anatomy } \\
\text { and Neurosciences, } \\
\text { Amsterdam UMC, the } \\
\text { Netherlands }\end{array}$ & $\begin{array}{l}\text { Helped in experimental data } \\
\text { collection }\end{array}$ \\
\hline $\begin{array}{l}\text { Jos W.R. } \\
\text { Twisk, PhD }\end{array}$ & $\begin{array}{l}\text { Department of } \\
\text { Epidemiology and } \\
\text { Biostatistics, Vrije } \\
\text { Universiteit, Amsterdam, } \\
\text { the Netherlands }\end{array}$ & $\begin{array}{l}\text { Provided support for the } \\
\text { statistical analysis and } \\
\text { statistical interpretation of } \\
\text { the data }\end{array}$ \\
\hline $\begin{array}{l}\text { Micha M.M. } \\
\text { Wilhelmus, } \\
\text { PhD }\end{array}$ & $\begin{array}{l}\text { Department of Anatomy } \\
\text { and Neurosciences, } \\
\text { Amsterdam UMC, the } \\
\text { Netherlands; }\end{array}$ & $\begin{array}{l}\text { Helped in the data } \\
\text { interpretation and provide } \\
\text { critical feedback on the } \\
\text { paper }\end{array}$ \\
\hline $\begin{array}{l}\text { Benjamin } \\
\text { Drukarch, } \\
\text { MD, PhD }\end{array}$ & $\begin{array}{l}\text { Department of Anatomy } \\
\text { and Neurosciences, } \\
\text { Amsterdam UMC, the } \\
\text { Netherlands; }\end{array}$ & $\begin{array}{l}\text { Helped in the data } \\
\text { interpretation and provided } \\
\text { critical feedback on the } \\
\text { paper }\end{array}$ \\
\hline $\begin{array}{l}\text { Charlotte E. } \\
\text { Teunissen, } \\
\text { PhD }\end{array}$ & $\begin{array}{l}\text { Department of Clinical } \\
\text { Chemistry, Amsterdam } \\
\text { UMC, the Netherlands }\end{array}$ & $\begin{array}{l}\text { Designed the study, } \\
\text { conceived the experiments } \\
\text { and helped in the data } \\
\text { interpretation, and provided } \\
\text { critical feedback on the } \\
\text { paper }\end{array}$ \\
\hline $\begin{array}{l}\text { Anne-Marie } \\
\text { van Dam, } \\
\text { PhD }\end{array}$ & $\begin{array}{l}\text { Department of Anatomy } \\
\text { and Neurosciences, } \\
\text { Amsterdam UMC, the } \\
\text { Netherlands }\end{array}$ & $\begin{array}{l}\text { Designed the study, } \\
\text { conceived the experiments } \\
\text { and helped in the data } \\
\text { interpretation, and provided } \\
\text { critical feedback on the } \\
\text { paper }\end{array}$ \\
\hline $\begin{array}{l}\text { Joep } \\
\text { Killestein, } \\
\text { MD, PhD }\end{array}$ & $\begin{array}{l}\text { Department of Neurology, } \\
\text { Amsterdam UMC, the } \\
\text { Netherlands }\end{array}$ & $\begin{array}{l}\text { Designed the study, } \\
\text { conceived the experiments } \\
\text { and helped in the data } \\
\text { interpretation, and provided } \\
\text { critical feedback on the } \\
\text { paper }\end{array}$ \\
\hline
\end{tabular}

\section{References}

1. Compston A, Coles A. Multiple sclerosis. Lancet 2008;372:1502-1517.

2. Reich DS, Lucchinetti CF, Calabresi PA. Multiple sclerosis. N Engl J Med 2018;378: 169-180.

3. Thompson AJ, Baranzini SE, Geurts J, Hemmer B, Ciccarelli O. Multiple sclerosis. Lancet 2018;391:1622-1636.

4. Weiner HL. Multiple sclerosis is an inflammatory T-cell-mediated autoimmune disease. Arch Neurol 2004;61:1613-1615.

5. Kirkpatrick Pinson DM, Ottens AJ, Fisher TA. Women coping successfully with multiple sclerosis and the precursors of change. Oual Health Res 2009;19:181-193.

6. Thorne S, Con A, McGuinness L, McPherson G, Harris SR. Health care communication issues in multiple sclerosis: an interpretive description. Qual Health Res 2004;14:5-22. Comabella M, Montalban X. Body fluid biomarkers in multiple sclerosis. Lancet Neurol 2014;13:113-126.

8. Khalil M, Teunissen CE, Otto M, et al. Neurofilaments as biomarkers in neurological disorders. Nat Rev Neurol 2018;14:577-589.

9. Oliverio S, Amendola A, Di Sano F, et al. Tissue transglutaminase-dependent posttranslational modification of the retinoblastoma gene product in promonocytic cells undergoing apoptosis. Mol Cell Biol 1997;17:6040-6048.

10. Robitaille K, Daviau A, Tucholski J, Johnson GV, Rancourt C, Blouin R. Tissue transglutaminase triggers oligomerization and activation of dual leucine zipper-bearing kinase in calphostin C-treated cells to facilitate apoptosis. Cell death diff 2004;11:542-549.

11. Davies PJ, Davies DR, Levitzki A, et al. Transglutaminase is essential in receptormediated endocytosis of alpha 2-macroglobulin and polypeptide hormones. Nature 1980;283:162-167.

12. Falasca L, Iadevaia V, Ciccosanti F, Melino G, Serafino A, Piacentini M. Transglutaminase type II is a key element in the regulation of the anti-inflammatory response elicited by apoptotic cell engulfment. J Immunol 2005;174:7330-7340. 
13. Akimov SS, Belkin AM. Cell surface tissue transglutaminase is involved in adhesion and migration of monocytic cells on fibronectin. Blood 2001;98:1567-1576.

14. Ruan Q Johnson GV. Transglutaminase 2 in neurodegenerative disorders. Front Biosci 2007;12:891-904.

15. van Strien ME, de Vries HE, Chrobok NL, et al. Tissue Transglutaminase contributes to experimental multiple sclerosis pathogenesis and clinical outcome by promoting macrophage migration. Brain Behav Immun 2015;50:141-154.

16. Chrobok NL, Bol JG, Wilhelmus MM, Drukarch B, van Dam AM. Tissue Transglutaminase appears in monocytes and macrophages but not in lymphocytes in white matter multiple sclerosis lesions. J Neuropathol Expl Neurol 2019;78:492-500.

17. Oh K, Park HB, Seo MW, Byoun OJ, Lee DS. Transglutaminase 2 exacerbates experimental autoimmune encephalomyelitis through positive regulation of encephalitogenic T cell differentiation and inflammation. Clin Immunol 2012;145:122-132.

18. Gupta R, Srinivasan R, Nijhawan R, Suri V. Tissue transglutaminase 2 as a biomarker of cervical intraepithelial neoplasia (CIN) and its relationship to p16INK4A and nuclear factor kappaB expression. Virchows Arch 2010;456:45-51.

19. Collin P, Kaukinen K, Vogelsang $\mathrm{H}$, et al. Anti-endomysial and antihuman recombinant tissue transglutaminase antibodies in the diagnosis of coeliac disease: a biopsy-proven European multicentre study. Eur J Gastroenterol Hepatol 2005;17: 85-91.

20. Dieterich W, Laag E, Schöpper H, et al. Autoantibodies to tissue transglutaminase as predictors of celiac disease. Gastroenterology 1998;115:1317-1321.

21. McDonald WI, Compston A, Edan G, et al. Recommended diagnostic criteria for multiple sclerosis: guidelines from the International Panel on the diagnosis of multiple sclerosis. Ann Neurol 2001;50:121-127.

22. Lublin FD, Reingold SC. Defining the clinical course of multiple sclerosis: results of an international survey. Neurology 1996;46:907-911.

23. Kurtzke JF. Rating neurologic impairment in multiple sclerosis: an expanded disability status scale (EDSS). Neurology 1983;33:1444-1452.

24. Ruijter JM, Ramakers C, Hoogaars $\mathrm{WMH}$, et al. Amplification efficiency: linking baseline and bias in the analysis of quantitative PCR data. Nucleic Acids Res 2009;37: e45.

25. Lukas C, Knol DL, Sombekke MH, et al. Cervical spinal cord volume loss is related to clinical disability progression in multiple sclerosis. J Neurol Neurosurg Psychiatry 2015;86:410-418.

26. Chard DT, Jackson JS, Miller DH, Wheeler-Kingshott CA. Reducing the impact of white matter lesions on automated measures of brain gray and white matter volumes. J Magn Reson Imaging 2010;32:223-228.

27. Popescu V, Battaglini M, Hoogstrate WS, et al. Optimizing parameter choice for FSLBrain Extraction Tool (BET) on 3D T1 images in multiple sclerosis. Neuroimage 2012;61:1484-1494.

28. Tukey JM. Exploratory Data Analysis. Addison-Wesley Pub Co; 1977.

29. Fernández-Aceñero MJ, Torres S, Garcia-Palmero I, Del Arco CD, Casal JI. Prognostic role of tissue transglutaminase 2 in colon carcinoma. Virchows Arch 2016;469: 611-619.
30. Moresco RN, Speeckaert MM, Zmonarski SC, et al. Urinary myeloid IgA Fc alpha receptor (CD89) and transglutaminase-2 as new biomarkers for active IgA nephropathy and henoch-Schonlein purpura nephritis. BBA Clin 2016;5:79-84.

31. Rubio-Tapia A, Hill ID, Kelly CP, Calderwood AH, Murray JA. ACG clinical guidelines: diagnosis and management of celiac disease. Am J Gastroenterol 2013; 108:656-676.

32. Sestito C, Breve JJP, Killestein J, et al. Differential expression of tissue transglutaminase splice variants in peripheral blood mononuclear cells of primary progressive multiple sclerosis patients. Med Sci (Basel) 2018;6:108.

33. Chrobok NL, Jaouen A, Fenrich KK, et al. Monocyte behaviour and tissue transglutaminase expression during experimental autoimmune encephalomyelitis in transgenic CX3CR1 gfp/gfp mice. Amino Acids 2017;49:643-658.

34. Sestito C, Breve JJP, van Eggermond M, et al. Monocyte-derived tissue transglutaminase in multiple sclerosis patients: reflecting an anti-inflammatory status and function of the cells? J Neuroinflammation 2017;14:257.

35. Martinez FO, Helming L, Milde R, et al. Genetic programs expressed in resting and IL-4 alternatively activated mouse and human macrophages: similarities and differences. Blood 2013;121:e57-e69.

36. Ishii I, Ui M. Possible involvement of GTP-binding proteins in 1 alpha,25 dihydroxyvitamin D3 induction of tissue transglutaminase in mouse peritoneal macrophages. Biochem Biophys Res Commun 1994;203:1773-1780.

37. Amendola A, Gougeon ML, Poccia F, Bondurand A, Fesus L, Piacentini M. Induction of "tissue" transglutaminase in HIV pathogenesis: evidence for high rate of apoptosis of CD4+ T lymphocytes and accessory cells in lymphoid tissues. Proc Nat Acad Sci USA 1996;93:11057-11062.

38. Kim JH, Hong JM, Jeong EM, et al. Lack of transglutaminase 2 diminished T-cell responses in mice. Immunology 2014;142:506-516.

39. Gunnarsson M, Malmestrom C, Axelsson $M$, et al. Axonal damage in relapsing multiple sclerosis is markedly reduced by natalizumab. Ann Neurol 2011;69:83-89.

40. Hakansson I, Tisell A, Cassel P, et al. Neurofilament light chain in cerebrospinal fluid and prediction of disease activity in clinically isolated syndrome and relapsingremitting multiple sclerosis. Eur J Neurol 2017;24:703-712.

41. Novakova L, Axelsson M, Khademi M, et al. Cerebrospinal fluid biomarkers as a measure of disease activity and treatment efficacy in relapsing-remitting multiple sclerosis. J Neurochem 2017;141:296-304.

42. Teunissen CE, Iacobaeus E, Khademi M, et al. Combination of CSF $\mathrm{N}$-acetylaspartate and neurofilaments in multiple sclerosis. Neurology 2009;72: 1322-1329.

43. Barro C, Benkert P, Disanto G, et al. Serum neurofilament as a predictor of disease worsening and brain and spinal cord atrophy in multiple sclerosis. Brain 2018;141: 2382-2391.

44. Disanto G, Barro C, Benkert P, et al. Serum neurofilament light: a biomarker of neuronal damage in multiple sclerosis. Ann Neurol 2017;81:857-870.

45. Abdelhak A, Huss A, Kassubek J, Tumani H, Otto M. Serum GFAP as a biomarker for disease severity in multiple sclerosis. Sci Rep 2018;8:14798. 


\section{Neurology \\ Neuroimmunology \& Neuroinflammation}

Tissue Transglutaminase Expression Associates With Progression of Multiple Sclerosis

Claudia Sestito, Cyra E. Leurs, Martijn D. Steenwijk, et al.

Neurol Neuroimmunol Neuroinflamm 2021;8;

DOI 10.1212/NXI.0000000000000998

This information is current as of April 27, 2021

\section{Updated Information \& Services}

References

Subspecialty Collections

Permissions \& Licensing

Reprints including high resolution figures, can be found at:

http://nn.neurology.org/content/8/4/e998.full.html

This article cites 44 articles, 6 of which you can access for free at: http://nn.neurology.org/content/8/4/e998.full.html\#\#ref-list-1

This article, along with others on similar topics, appears in the following collection(s):

Autoimmune diseases

http://nn.neurology.org//cgi/collection/autoimmune_diseases

Class II

http://nn.neurology.org//cgi/collection/class_ii

MRI

http://nn.neurology.org//cgi/collection/mri

Multiple sclerosis

http://nn.neurology.org//cgi/collection/multiple_sclerosis

Information about reproducing this article in parts (figures,tables) or in its entirety can be found online at:

http://nn.neurology.org/misc/about.xhtml\#permissions

Information about ordering reprints can be found online:

http://nn.neurology.org/misc/addir.xhtml\#reprintsus

Neurol Neuroimmunol Neuroinflamm is an official journal of the American Academy of Neurology.

Published since April 2014, it is an open-access, online-only, continuous publication journal. Copyright

Copyright $\left({ }^{\circ} 2021\right.$ The Author(s). Published by Wolters Kluwer Health, Inc. on behalf of the American

Academy of Neurology.. All rights reserved. Online ISSN: 2332-7812.

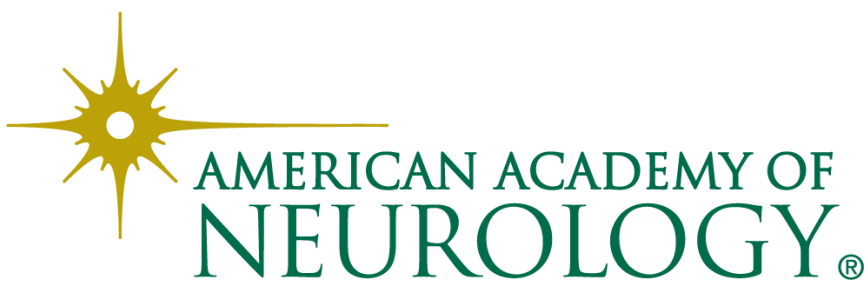

